DOI: $10.5604 / 20830157.1130206$

\title{
CHARACTERISATION OF NANOFIBROUS SEPARATORS FOR LITHIUM-ION BATTERIES
}

\author{
Michal Musil, David Pléha \\ Brno University of Technology, Faculty of Electrical Engineering and Communication, Czech Republic
}

Abstract. Nano fibred materials ensure high porosity and relative surface area of separators. These parameters are important to improve ionic mobility between electrodes and ensure sufficient electrolyte volume in battery. These advantages make electrospinning very promising method of nanofibrous separators mass production. In this paper are described electrospinning fabrication process and discussed results of separator's electric and electrochemical properties measurements compared with Celgard 3401.

Keywords: spinning, battery, separator, impedance measurement

\section{CHARAKTERYSTYKA SEPARATORÓW Z NANOWEÓKIEN DLA BATERII LITOWO-JONOWYCH}

Streszczenie. Nanostruktura materiałów wykorzystywanych jako separatory zapewnia ich wysoka porowatość, a co za tym idzie duża powierzchnię właściwą. Parametry te sa ważne $w$ kontekście podwyższenia mobilności jonów (Ion mobility) i zagwarantowania wystarczającej ilości elektrolitu w baterii. Korzyści te pozwalaja upatrywać w elektro wirowanie bardzo obiecująca metodę masowej produkcji separatorów z nanowłókien. W niniejszym artykule opisany zostaje proces produkcji separatorów. Omawia się również wyniki pomiarów elektrycznych $i$ elektrochemicznych $w$ porównaniu do Celgrad 3401 .

Słowa kluczowe: wirowanie, bateria, separator, pomiar impedancji

\section{Introduction}

Battery separators play very important role in rechargeable lithium-ion batteries and determine the battery performance. The main function of these is to keep the positive and negative electrodes apart to prevent electrical short circuits while enabling free ionic transport.

Microporous separators based on polypropylene and polyolefine are the most used ones in contemporary commercial li-ion batteries. The reason is its properties suitable for this purpose. These separators demonstrate high chemical stability, appropriate thickness, tensile strength and toughness. As a negative properties of commercial separators occur low porosity, low thermal stability, wettability and ability to uptake electrolyte. Low wettability and ability to uptake electrolyte are both caused by polarity difference between non-polar separator (polyolefine) and highly polar electrolyte containing solvent. This fact may lead to increase in battery cell resistance and subsequently to battery capacity drop [5].

Wettability increase can be ensured by the surfactant addition. Nevertheless, surfactants may affect electrolyte and electrodes in a negative way. Usage of nanofibred separators prevents from that negative factors. Nanofibred separator production is realized by electrospinnig or forcespinning [3].

Nafigate nanofibred separators were fabricated by electrospinning method. Fibres were spinned from the free surface of polymer. Thanks to higher porosity of nanofibred separators, dissociated ions exhibit higher mobility between cathode and anode. It results in better electrochemical properties. Chemical resistance depends on the used material [7].

\section{Separator fabrication}

Experimental samples of nano fibred separators are fabricated in the laboratory machine Nanospider ${ }^{\mathrm{TM}}$ NS LAB 500 equipped with EMW (Endless Motion Wire) technology. This EMW technology is based on spinning by the string electrode with usage of a small amount of polymer solution. Polymer solution is applied (the rate of application is set) on the string (spin electrode). Intensive electrostatic field, which results from potential difference between spin and collecting electrodes, forms Taylor's cone. This cone is fibre source. Drawn fibre is subsequently elongated, surface area increases and solvent evaporates simultaneously. Properly adjusted Nanospider (electrodes position, solvent selection) produces sub-micron wide dry fibres. Electric charge carried by the produced fibres has the same polarity as the spin electrode. This charge is drained onto collector and usually grounded [7]. Nanospider scheme is shown in Figure 1.

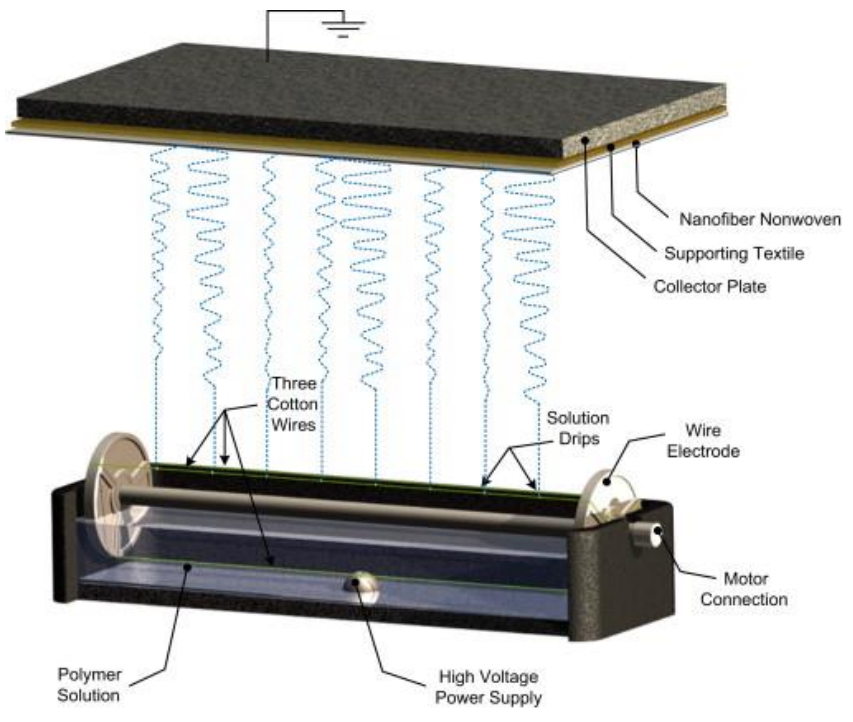

Fig. 1. Nanospider scheme with main parts description [7]

This method is convenient for spinning organic and inorganic polymers and biopolymer materials. Electrospinning is widely spread in the industry because of its simple machine design, with no need of sophisticated jet systems. It brings quality production improvement simultaneously. Nanofibres produced by spinning from the free surface exhibit better uniformity in diameter. Applied nanofibred layers are more homogenous. Diameter of produced nanofibers are usually in range from 50 to $500 \mathrm{~nm}$ (according to used material). Electrospinning process exhibits productivity from 0.1 to $1 \mathrm{~g} \mathrm{~h}^{-1}$. Nanospider ${ }^{\mathrm{TM}}$ system exhibits productivity according to individual properties of used material. Fabrication process is dependent on critical parameters optimization. It means machine configuration (distance between electrodes, potential voltage), polymer solution properties (concentration, viscosity, conductivity), appropriate substrate type and surrounding environment properties. Modern technologies enable us to set fabrication properties very simply, but exactly. Up to date methods allow nanofibres production from in water soluble polymers, from polymers dilutable in organic solvents and from polymer melts. We are capable to spin more than 30 polymer types $[4,7]$. 


\section{Results and discussion}

\subsection{Ageing and liquid uptake in the aprotic electrolyte}

Separators must be resistant to carbonate aprotic solvents without limits, and must not lose neither its tensile strength not its toughness. Analyzed samples were long period aged in $1 \mathrm{~mol} \mathrm{l}^{-1}$ $\mathrm{LiBF}_{4}$ in EC/DMC electrolyte. Samples were checked on mechanical properties and structural changes dependent on time. Furthermore, mass changes during time period were studied. Weight of samples did not change during time. It proves very promising inertness of Nafigate separators soaked in carbonate solvents.

The liquid electrolyte uptake is one of the most important parameters. Separators should have high ability to uptake and retain electrolyte in long-term. Each of the Nafigate samples was measured on this property. Separators were measured by soaking them in a liquid $1 \mathrm{~mol} \mathrm{l}^{-1} \mathrm{LiBF}_{4}$ in EC/DMC (1:1 wt.) electrolyte for $4 \mathrm{~h}$ at $20{ }^{\circ} \mathrm{C}$ to reach the equilibrium state. The residual electrolyte on the surface of each separator was wiped off with filter paper. [1, 6, 9]. The liquid electrolyte uptake $E U(\%)$ was calculated according to:

$$
E U=\frac{m_{w}-m_{d}}{m_{d}} \times 100 \%
$$

where $m_{\mathrm{w}}$ a $m_{\mathrm{d}}$ are weights of the electrolyte-soaked separator and dry separator, respectively.

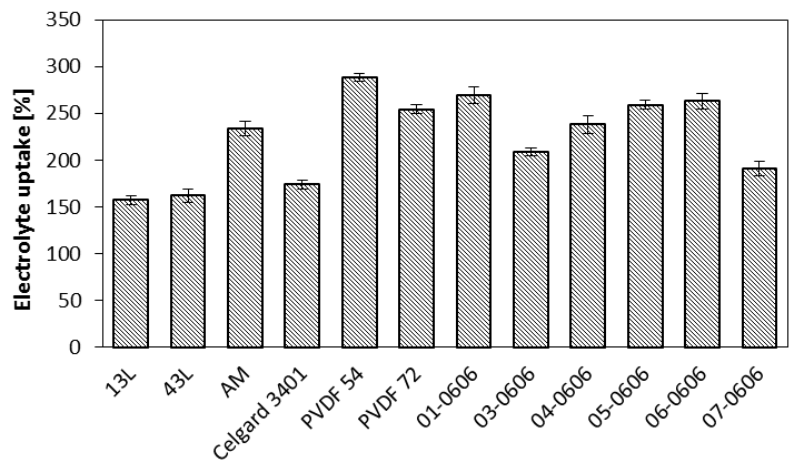

Fig. 2. Electrolyte uptake of Nafigate and Celgard separators, $20^{\circ} \mathrm{C}$

Figure 2 shows the liquid electrolyte uptakes of Nafigate fibrous membranes. The majority of liquid electrolyte is distributed in the open pores. Commercial separator Celgard 3401 uptakes slightly higher amount of electrolyte in contrary to $13 \mathrm{~L}$ and 43L types. Other Nafigate types prove EU over $200 \%$. These characteristics correlate with the PVP content in Nafigate separators.

\subsection{Surface morphology}

Morphology was studied by the environmental scanning electron microscope (ESEM, TESCAN, a.s., Vega 3 XMU) which was operated at $30 \mathrm{kV}$. Small samples (area $1 \mathrm{sq} . \mathrm{cm}$ ) were cleaned with compressed air duster and dried at $30{ }^{\circ} \mathrm{C}$ for $24 \mathrm{~h}$ before observation. Micrographs were taken at resolutions $5000 \times$ at $30 \mathrm{kV}$ in the inert argon atmosphere (low pressure set to $100 \mathrm{~Pa}$ ).

During nanofibred materials fabrication, some basic defects may occur. Fabrication process is continuously optimized. Figure $3 \mathrm{a}$ and $3 \mathrm{~b}$ shows ESEM images of studied membranes. Sample 01_0606 (a) exhibits material conglomerations (beads) in the bulk of the separator. Separator type 03_0606 (b) contains visibly wider fibres (ropes). Rope - effect occurs in 05_0606 (c) too. Nanofibred separator 7_0606 (d) contains considerable beads. Items of each sample pairs PVDF 54 (e) - PVDF 7209 (f) and 43L (g) - 13L (h) were fabricated in the same way. Differences are only in the amount of used crosslinker. Samples (e) and (f) are single-layer types, where conglomerations and lack of uniformity may occur. Samples (g) and (h) are represented by three-layer laminates. $43 \mathrm{~L}$ and $13 \mathrm{~L}$ separators prove higher tensile strength. In the 13L sample higher amount of particles appeared, nevertheless beads did not occur. Used electrostatic electrospinning fabrication method advantages are in splashes a droplets defects elimination $[2,11]$.

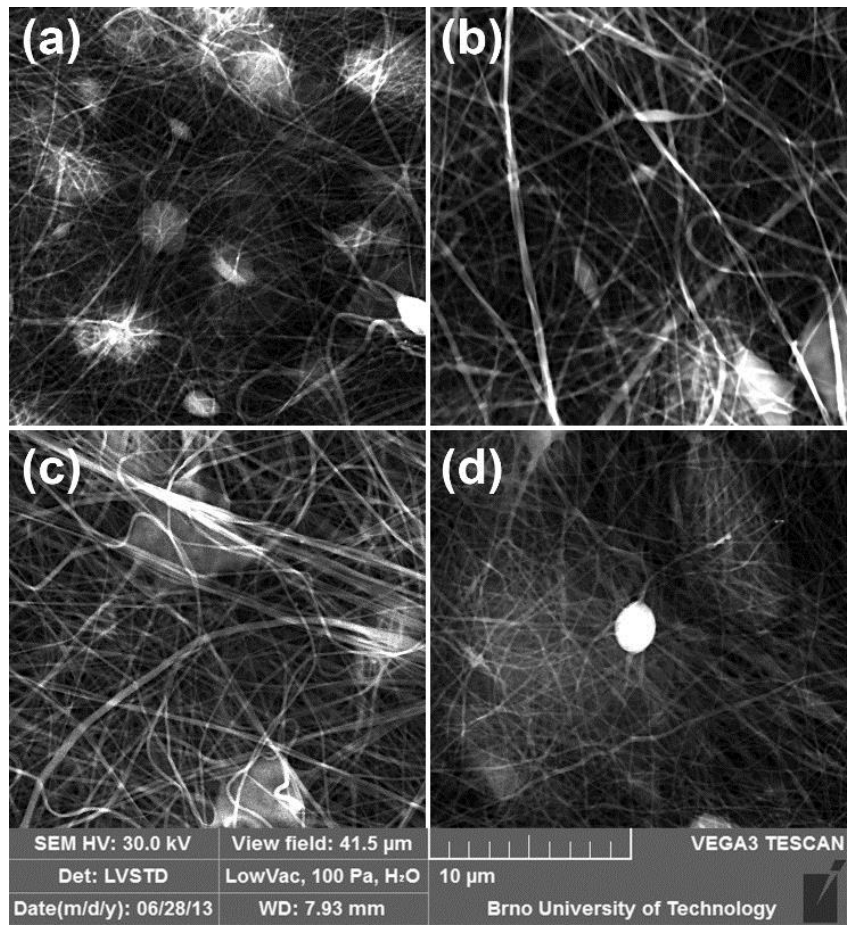

Fig. 3a. ESEM images of Nafigate fibrous membranes (a) 01_0606, (b) 03_0606, (c) 05_0606, (d) 07_0606

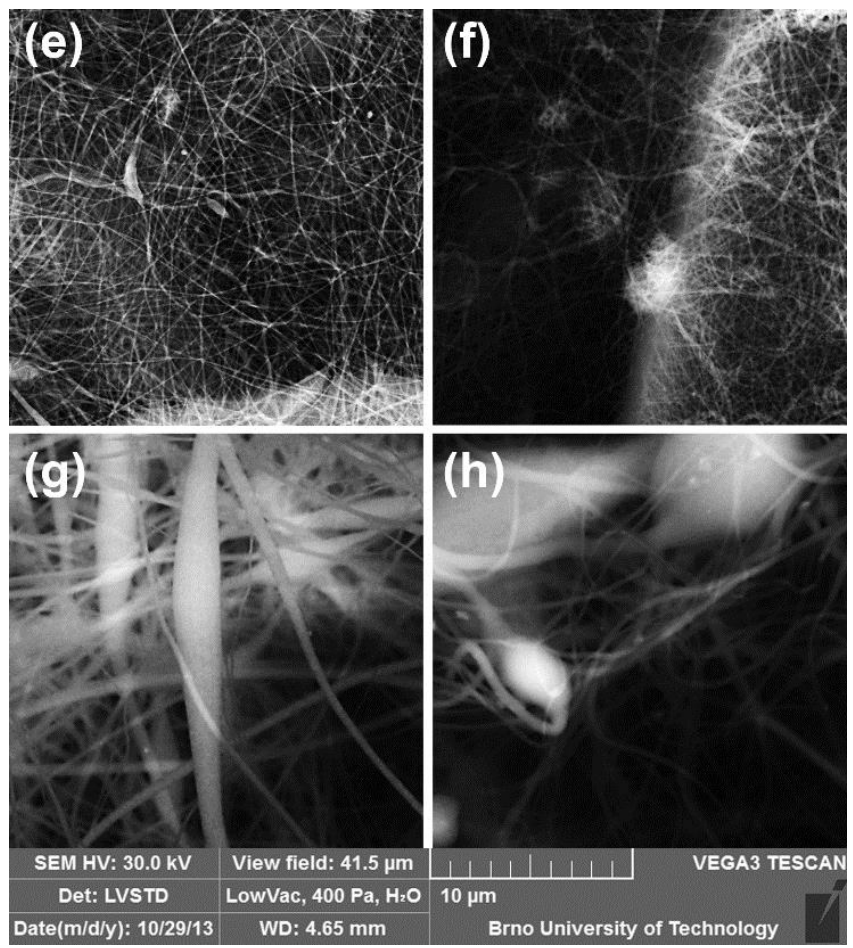

Fig. 3b. ESEM images of Nafigate fibrous membranes (e) PVDF 54, (f) PVDF 7209, (g) $43 L$, (h) $13 L$

\subsection{Impedance behavior of nanofibrous separators and ionic conductivity}

Impedance spectroscopy was run on potentiostat VSP Biologic. All samples were immersed in $1 \mathrm{~mol} \mathrm{l}^{-1} \mathrm{LiBF}_{4}$ in EC/DMC electrolyte and tempered in the climate chamber with temperature set at $20{ }^{\circ} \mathrm{C}$ simultaneously. Separator circles 
(16 millimeters in diam.) were measured in electrochemical test cells EL-CELL at frequency range $0.5 \mathrm{~Hz}-1 \mathrm{MHz}$ with amplitude $10 \mathrm{mV}$. All the process took place in the inert argon atmosphere $[8,10]$. Ionic conductivity measurement results are shown in the Nyquist plot (see Figure $4 \mathrm{a}$ and $4 \mathrm{~b}$ below).

Ionic conductivity $(\sigma)$ was calculated according to the equation below:

$$
\sigma=\frac{d}{R_{b} S}
$$

where $R_{\mathrm{b}}$ is the bulk resistance, $d$ and $S$ are thickness and area of the sample [7].

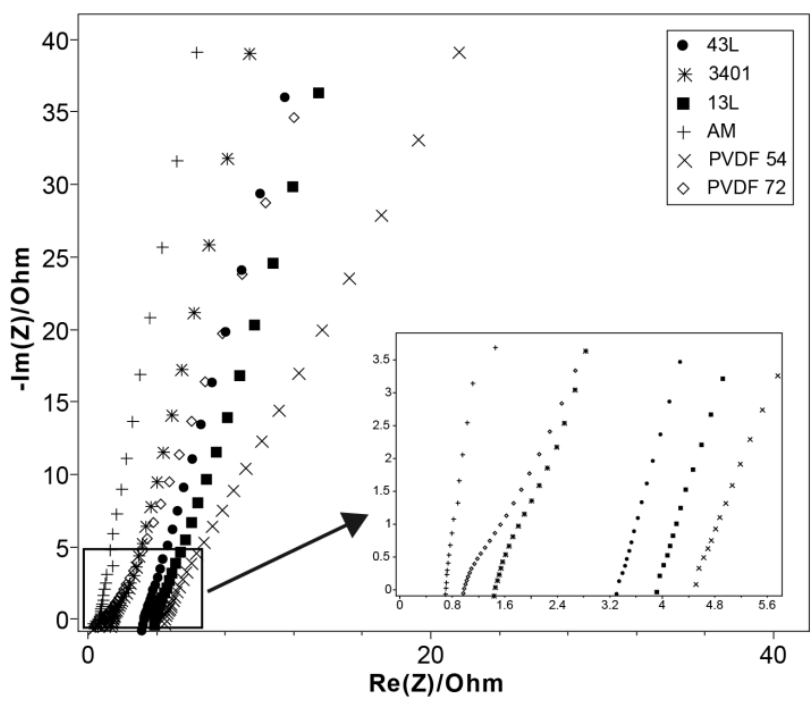

Fig. 4a. Membrane impedance spectra, $1 \mathrm{~mol}^{-1} \mathrm{LiBF}_{4}$ in EC/DMC electrolyte, $20^{\circ} \mathrm{C}$

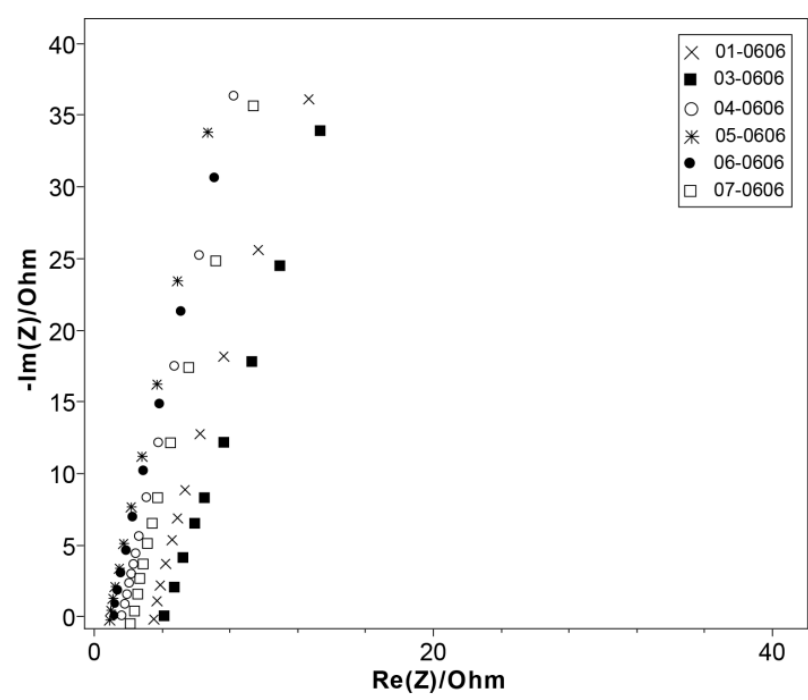

Fig. 4b. Membrane impedance spectra, $1 \mathrm{~mol}^{-1} \mathrm{LiBF}_{4}$ in EC/DMC electrolyte, $20^{\circ} \mathrm{C}$

Bulk resistance $R_{\mathrm{b}}$ was read from the low frequencies of impedance spectra in Nyquist plot. It is clarified in Figure 5.

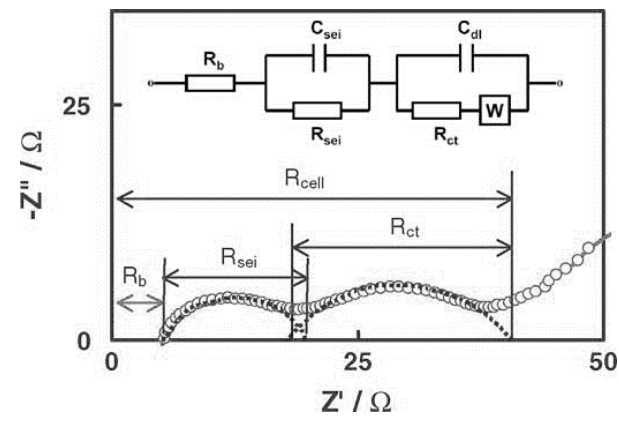

In Table 1 are summarized $R_{\mathrm{b}}$ and $\sigma$ values of all measured separators.

Table 1. Thickness and relative conductivity of membrane, frequency range $0.5 \mathrm{~Hz}-1 \mathrm{MHz}, 20^{\circ} \mathrm{C}$

\begin{tabular}{|c|c|c|}
\hline Sample & $\boldsymbol{R}_{\mathbf{b}}[\boldsymbol{\Omega}]$ & Conductivity $\boldsymbol{\sigma}\left[\mathbf{m S ~ \mathbf { ~ m } ^ { - 1 }}\right]$ \\
\hline 13L & 3.91 & 1.97 \\
\hline 43L & 3.34 & 2.89 \\
\hline AM & 0.69 & 1.35 \\
\hline Celgard 3401 & 5.31 & 0.23 \\
\hline PVDF 54 & 4.52 & 0.70 \\
\hline PVDF 72 & 0.97 & 4.17 \\
\hline $01-0606$ & 2.75 & 0.28 \\
\hline $03-0606$ & 2.08 & 0.45 \\
\hline $04-0606$ & 1.61 & 0.61 \\
\hline $05-0606$ & 0.81 & 1.61 \\
\hline $06-0606$ & 0.87 & 0.95 \\
\hline $07-0606$ & 2.05 & 0.36 \\
\hline
\end{tabular}

\subsection{Dielectric properties of separators}

Dielectric properties were determined by a dielectric properties tester (Agilent 4285A, Precision LCR Meter). Measurements were carried out with frequencies $100 \mathrm{~Hz}$ and 1 $\mathrm{kHz}$. Results are summarized in Table 2. It was not possible to determine dielectric properties of sample 01-0606. Pressure between measuring electrodes always affected tears on the surface.

Table 2. Relative permittivity ( $100 \mathrm{~Hz}$ and $1 \mathrm{kHz}$ respectively) of fibrous separators, $20^{\circ} \mathrm{C}$

\begin{tabular}{|c|c|c|}
\hline \multirow{2}{*}{ Sample } & \multicolumn{2}{|c|}{ Relative permittivity $\boldsymbol{\varepsilon}_{\mathbf{r}}[-]$} \\
\cline { 2 - 3 } & $\mathbf{1 0 0} \mathbf{~ H z}$ & $\mathbf{1 ~ k H z}$ \\
\hline 13L & 8.24 & 4.32 \\
\hline 43L & 2.62 & 2.03 \\
\hline AM & 4.62 & 2.05 \\
\hline Celgard 3401 & 2.61 & 2.01 \\
\hline PVDF 54 & 1.77 & 1.67 \\
\hline PVDF 72 & 1.62 & 1.53 \\
\hline $01-0606$ & - & - \\
\hline $03-0606$ & 1.11 & 1.19 \\
\hline $04-0606$ & 1.28 & 1.28 \\
\hline $05-0606$ & 2.82 & 1.41 \\
\hline $06-0606$ & 1.23 & 1.29 \\
\hline $07-0606$ & 1.11 & 1.12 \\
\hline
\end{tabular}

Values of permittivity at frequency $100 \mathrm{~Hz}$ correspond to tabulated values (samples 3401 and 13L). Separator 43, which is mainly made from polyethersulfone (PES), practically corresponds to tabulated value $\left(\varepsilon_{\mathrm{r}}=3.5\right.$ at frequency $\left.100 \mathrm{~Hz}\right)$. Permittivity values of 01-0606 - 07-0606 depends on different concentration of added polyvinylpyrrolidine additive. Differences are caused by non-homogeneousness and high porosity of the separator's surface.

\subsection{Performance of Nafigate separators in half-cell}

Separator influence on battery performance was measured in three electrode electrochemical test cell EL-CELL (diameter $18 \mathrm{~mm}$ ). Test cells representing lithium ion half-cell consisted of metallic lithium counter (CE) and reference (RE) electrodes. As a working electrode (WE) was chosen anode. Negative electrode in commercial lithium ion batteries is made from materials based on carbon. We prepared our WE from graphite COND CR 5995. Test cells were assembled in the inert argon atmosphere. We employed common liquid electrolyte $1 \mathrm{~mol} / \mathrm{l}$ $\mathrm{LiBF}_{4}$ in EC/DMC (50:50 wt. \%) in test cells.

Half-cell was measured on Galvanostatic Cycling with Potential Limitation (GCPL). This method enabled us to control electrochemical half-cell potential at cycled charge and discharge. In first two cycles was half-cell formatted (double layer on the interface electrode-electrolyte was stabilized). Formatting is linked to electrode characteristics changes - irreversible capacity of the half-cell, impedance of both electrode and electrode material; coulombic efficiency. 


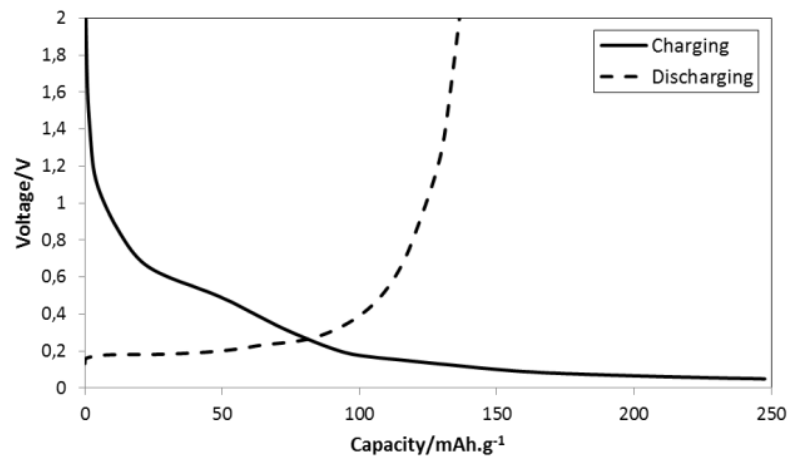

Fig. 6a. First cycle charge and discharge performance of the half-cell with Nafigate separator 05-0606 soaked in $1 \mathrm{~mol} \mathrm{l}^{-1} \mathrm{LiBF}_{4}$ electrolyte, $20^{\circ} \mathrm{C}$

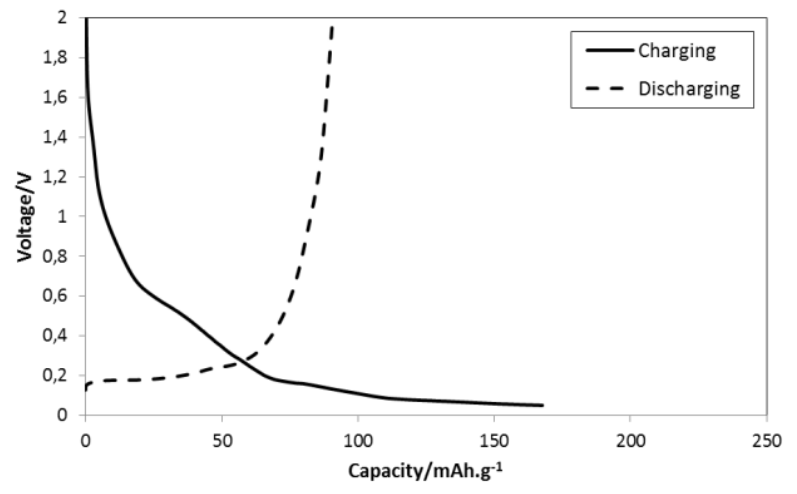

Fig. 6b. First cycle charge and discharge performance of the half-cell with Nafigate separator 06-0606 soaked in $1 \mathrm{~mol}^{-1} \mathrm{LiBF}_{4}$ electrolyte, $20^{\circ} \mathrm{C}$

In figure $6 \mathrm{a}$ and $6 \mathrm{~b}$ are shown charge and discharge characteristics of the lithium-ion half-cells equipped with separator 05-0606 and separator 06-0606 respectively. It is obvious, that half-cell with Nafigate separator 05-0606 proves higher first charge capacity in comparison with half-cell with 060606 type. It may by caused by the lower porosity of 06-0606 sample. In the bulk of the 06-0606 separator runs glomer formation process. Glomer consists of solvent components, which are affiliated to separator fibres. Measurement was performed in the potential range from $0 \mathrm{~V}$ to $2 \mathrm{~V}$ and current set on $\mathrm{C} / 10$. Measurement was carried out at $25^{\circ} \mathrm{C}$ and relative humidity $49 \%$. Furthermore, half-cell with 05-0606 separator reached first cycle charge capacity $249 \mathrm{mAh} \mathrm{g}^{-1}$ in contrast to 06-0606 half-cell with only first cycle capacity of $167 \mathrm{mAh} \mathrm{g}^{-1}$.

\section{Conclusion}

This report is focused on measuring properties of noncommercial separators from the Nafigate Corporation stock company. Properties of separators are compared with on the market widely spread separator Celgard 3401. Nafigate separators were prepared by electrospinning. Samples were tested on ionic conductivity and influence on characteristic of lithiumion half-cell. These Nafigate separators (especially AM model) have all the important parameters comparable with the world production. Further work will be focused on development of very promising AM types with internal sandwich structure. Moreover, we are in co-operation with Nafigate focused on trimming fabrication time of new separators.

\section{Acknowledgements}

Authors gratefully acknowledge financial support from the grant FEKT-S-14-2293.

\section{References}

[1] Abraham K. M., Alamgir M., Hoffman D. K.: Polymer Electrolytes Reinforced by Celgard ${ }^{\circledR}$ Membranes. Journal of The Electrochemical Society 142/1995, $1347-1354$

[2] Cech O., Thomas J. E., Sedlarikova M., Fedorkova A., Vondrak J., Moreno M. S., Visintin A.: Performance improvement on LiFePO4/C composite cathode for lithium-ion batteries. Solid State Sciences 20/2013, 110-114.

[3] Cho T., Sakai T., Tanase S., Kimura K., Kondo Y., Tarao T., Tanaka M. Electrochemical Performances of Polyacrylonitrile Nanofiber-Based Nonwoven Separator for Lithium-Ion Battery. Electrochemical and Solid-State Letters 10/2007, A159-A162.

[4] Ding B., Kim C., Kim H., Seo M., Park S.: Titanium dioxide nanofibers prepared by using electrospinning method. Fibers and Polymers 5/2004, 105-109.

[5] Duan B., Yuan X., Zhu Y., Zhang Y., Li X., Zhang Y., Yao K.: A nanofibrous composite membrane of PLGA-chitosan/PVA prepared by electrospinning. European Polymer Journal 42/2006, 2013-2022.

[6] Jung H., Ju D., Lee W., Zhang X., Kotek R.: Electrospun hydrophilic fumed silica/polyacrylonitrile nanofiber-based composite electrolyte membranes. Electrochimica Acta 54/2009, 3630-3637.

[7] Nanospider: Technologie electrospinningu. Elmarco. 2013, http://old.elmarco.com/obsah.php?id=27\&s=2

[8] Pleha D., Dvorak P., Kunovjanek M., Musil M., Cech O.: Battery Separators ECS Trans. 2012 40(1)/2012, 153-155.

[9] Yang C., Jia Z., Guan Z., Wang L.: Polyvinylidene fluoride membrane by nove electrospinning system for separator of Li-ion batteries. Journal of Power Sources 189/2009, 716-720

[10] Zhang S. S., Xu K., Jow T.R.: Electrochemical impedance study on the low temperature of Li-ion batteries. Electrochimica Acta. issue 7/2004, 1057-1061. DOI http://dx.doi.org/10.1016/j.electacta.2003.10.016.

[11] Zhao Z., Zheng J., Wang M., Zhang H., Han C.: High performance ultrafiltration membrane based on modified chitosan coating and electrospun nanofibrous PVDF scaffolds. Journal of Membrane Science 394395/2012, 209-217.

\section{Ing. Michal Musil}

Ing. David Pléha

e-mail: michal.musil@phd.feec.vutbr.cz

Eng. Michal Musil and Eng. David Plecha are doctoral students of the Faculty of Electrical Engineering and Communication Technology at the Technical University in Brno. Both work within the Centre for the development and utilization of renewable energy sources. According to VAVAI data David Plecha in the period from 2011 to 2013 and Michal Musil in the period 2010-2014 released 28 scientific publications in national and international journals and conference proceedings volumes. They take an active part in international conferences. Their dissertations are focused on the issue of the use of different types of separators in $\mathrm{Li}$-ion batteries and gel polymer electrolytes used in $\mathrm{Li}$-ion batteries.
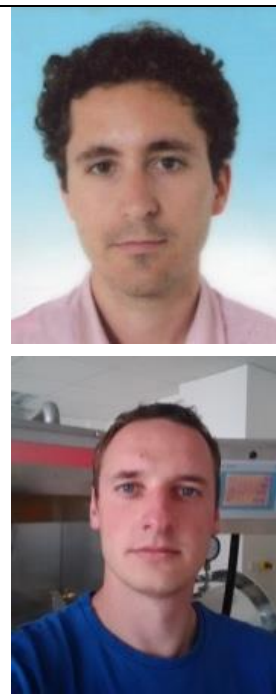

otrzymano/received: 2014.06 .27 